6. Ольшанский Д. В. Психология масс / Дмитрий Вадимович Ольшанский. - СПб. : Питер, 2002. - 368 с.

7. Почепцов Г. Теория коммуникации / Георгий Почепцов. - М. : Рефлбук, К. : Ваклер, 2001. - 565 с.

8. Рекламный дискурс и рекламный текст : [кол. монография] / науч. ред. Н. Т. Колокольцева. - М. : Флинта : Наука, 2011. - 296 с.

9. Різун В. В. До питання про соціальнокомунікаційний підхід у науці / Володимир Володимирович Різун // Комунікація : Влада - медія суспільство. - К. : К.І.С. - 2010. - № 1. - С. 27-37.

10. Ромат Е. В. Реклама : [учебник] / Евгений Викторович Ромат. -3 е изд., перераб. и доп. - К. ; Х. : НВФ Студцентр, 2000. - 480 с.

11. Теркулова Д. Р. Лингвостилистичекские и коммуникативнопрагматические особенности английского рекламного текста : автореф. дис. на соискание учен. степени канд. филол. наук : спец. 10.02.04 «Германские языки» / Дина Раильевна Теркулова. - М., 2004. -24 c.

12. Философский энциклопедический словарь [сост. Л. Ф. Ильичева и др.]. - М. : Современная энциклопедия, 1983. - 840 с.

DOI: http://doi.org/10.31617/k.knute.2019-03-19.17

\title{
СОЦІАЛЬНА РЕКЛАМА: СУТНІСТЬ, КЛАСИФІКАЦІЯ ТА ОСОБЛИВОСТІ РОЗВИТКУ
}

\author{
Балук Н.Р. \\ к.е.н., доцент \\ Басій Н.Ф. \\ к.е.н., доцент \\ Дайновський Ю.А. \\ д.е.н., професор \\ кафедра маркетингу \\ ЛТЕУ, Україна
}

Ключові слова: сочіальна реклама, тип соціальної реклами, суспільні иінності.

Keywords: social advertising, type of social advertising, social values.

Основна мета комерційної реклами - продати продукт, тобто все, що може бути об'єктом маркетингу. Основна мета некомерційної реклами - змінити ставлення громадськості до певних явищ, подій, цінностей та ситуацій, а також створення нових суспільних цінностей, 
зміна поведінкових моделей в суспільстві. До некомерційної реклами більшість авторів відносять політичну, державну рекламу, рекламу територій, особисту рекламу і власне соціальну рекламу [1, с. 129].

Чинне законодавство визначає соціальну рекламу як інформацію будь-якого виду, розповсюджену в будь-якій формі, яка спрямована на досягнення суспільно корисних цілей, популяризацію загальнолюдських цінностей і розповсюдження якої не має на меті отримання прибутку [2]. В інших джерелах під соціальною рекламою мають на увазі інформацію з питань здорового способу життя, охорони здоров'я, екології, збереження енергоресурсів, профілактики правопорушень, соціального захисту та безпеки населення, яка не має комерційного характеру і спрямована на дітей, підлітків, молодь, жінок, різні категорії сімей [3]. Л. Гейдар і Г.Довбах вважають соціальну рекламу освітнім засобом, який здатний ефективно впливати і мотивувати значну за обсягом аудиторію [4]. Ромат С.В. визначає ціль соціальної реклами у формуванні певних психологічних установок, які повинні сприяти досягненню суспільно значимих цілей на різних рівнях: від окремих соціальних груп до суспільства в цілому [1, с. 137].

Безперечно, соціальну рекламу можна визначити як специфічну форму впливу на масову аудиторію з метою управління іiі поведінкою. Цей вид реклами більшістю аудиторій сприймається більш лояльно, ніж комерційну рекламу.

Таблиия 1

\section{Класифікація соціальної реклами}

\begin{tabular}{|c|c|}
\hline Класифікаційна ознака & Тип соціальної реклами \\
\hline За типом рекламодавця & $\begin{array}{l}\text { - реклама, що розміщується державними структурами } \\
\text { - реклама від імені некомерційних організацій, громадських } \\
\text { установ } \\
\text { - реклама від імені асоціацій, професійних об’єднань } \\
\text { - реклама комерційних організацій }\end{array}$ \\
\hline $\begin{array}{l}\text { За характером цілей } \\
\text { реклами }\end{array}$ & $\begin{array}{l}\text { - реклама, спрямована на вирішення взаємостосунків між } \\
\text { різними соціальними групами } \\
\text { - реклама, спрямована на вирішення взаємостосунків між } \\
\text { суспільством й індивідом } \\
\text { - реклама, спрямована на вирішення взаємостосунків між } \\
\text { суспільством та різними організаціями } \\
\text { - реклама, спрямована на вирішення міжособистісних } \\
\text { взаємостосунків } \\
\text { - реклама, спрямована на вирішення взаємостосунків між } \\
\text { суспільством і навколишнім середовищем }\end{array}$ \\
\hline
\end{tabular}


Закінчення табл. 1

\begin{tabular}{|c|c|}
\hline Класифікаційна ознака & Тип соціальної реклами \\
\hline & $\begin{array}{l}\text { - реклама, спрямована на вирішення ставлення індивіда до } \\
\text { себе самого } \\
\text { - реклама, спрямована на вирішення взаємостосунків між } \\
\text { державою й індивідом }\end{array}$ \\
\hline За характером впливу & $\begin{array}{l}\text { - раціональна } \\
\text { - емоційна } \\
\text { - моральна }\end{array}$ \\
\hline За характером змісту & $\begin{array}{l}\text { - інформативно-культурна } \\
\text { - інформативно-професійна } \\
\text { - інформаційно-запрошувальна } \\
\text { - інформативно-виховна } \\
\text { - інформативно-освітня }\end{array}$ \\
\hline $\begin{array}{l}\text { За масштабом впливу на } \\
\text { аудиторію }\end{array}$ & $\begin{array}{l}\text { - масова } \\
\text { - селективна }\end{array}$ \\
\hline $\begin{array}{l}\text { За об’єктом } \\
\text { рекламування }\end{array}$ & $\begin{array}{l}\text { - реклама суспільних цінностей } \\
\text { - реклама моделей поведінки } \\
\text { - реклама місії та цілей організації } \\
\text { - реклама соціальної проблеми та іï вирішення } \\
\text { - реклама окремих людей, їх діяльності, форм роботи } \\
\text { - реклама важливих суспільно значимих проектів } \\
\text { - реклама досягнень організації та їі діяльності в цілому }\end{array}$ \\
\hline За масштабом дії & $\begin{array}{l}\text { - глобальна } \\
\text { - національна } \\
\text { - регіональна } \\
\text { - локальна }\end{array}$ \\
\hline
\end{tabular}

Джерело :складено за $[1 ; 3 ; 4 ; 5 ; 6]$.

В табл. 1 наведено зведену за літературними джерелами класифікацію соціальної реклами. Більшість дослідників рекламного ринку сходяться на думці, що основними суб'єктами ринку соціальної реклами є держава, державні інститути, некомерційні організації і політичні партії. Проте за останні роки соціальну рекламу активно застосовують і комерційні організації для популяризації певних ідей, дотичних до їх діяльності (наприклад, автомобільні концерни про використання альтернативних типів палива; інші компанії про захист навколишнього середовища, охорону тваринного і рослинного світу тощо). 
Кінцевим результатом дії соціальної реклами повинна бути гармонізація відносин в суспільстві з приводу певних подій, ситуацій, явищ тощо, позитивна динаміка змін відносин між громадськістю, державними структурами, комерційними і некомерційними організаціями. Створюючи сильні еталони дій (щасливі люди, правильні вчинки), соціальна реклама повинна змінювати існуючі координати цінностей, ставати внутрішнім орієнтиром дій і в кінцевому підсумку частиною світогляду кожного громадянина та суспільства в цілому.

\section{Список використаних джерел}

1. Ромат Е. В. Реклама : учеб. для вузов. / Е. В. Ромат. - [7-е изд.]. СПб. : Питер, 2008. - 512 с.

2. Закон України. Про рекламу [Електронний ресурс] / Законодавство України. - Відомості Верховної Ради України (ВВР), 1996, N 39, ст. 181. - Режим доступу : https://zakon2.rada.gov.ua/laws/show/270/96$\% \mathrm{D} 0 \% \mathrm{~B} 2 \% \mathrm{D} 1 \% 80$.

3. Словник-довідник для соціальних педагогів та соціальних працівників / [за заг. ред. А.Й. Капської, І.М. Пінчук, С.В. Толстоухової]. К., 2000. - С. 194.

4. Гейдар Л. Соціальна реклама та інформування ВІЛ/СНІД в Україні: можливість впливу на зміни у поведінкових практиках / Л. Гейдар, Г. Довбах [Електронний ресурс]. - Режим доступу : http://feminist.org.ua/library/psihologia/aids.php.

5. Стрелковська А. Л. Соціально-педагогічні умови формування позитивно спрямованої поведінки молоді засо- бами соціальної реклами: автореф. дис. на здобуття наук. ступеня канд. пед. наук: спец. 13.00.05 «Соціальна педагогіка» / А. Л. Стрелковська. - К., 2007. $-25 \mathrm{c}$.

6. Докторович М. О. Соціальна реклама: структура, функції, психологічний вплив / М. О. Докторович // Вісник Чернігівського національного педагогічного університету. - Сер. : Педагогічні науки. 2014. - Вип. 115. - С. 70-73. 